\title{
Calcium Current Diversity in Physiologically Different Local Interneuron Types of the Antennal Lobe
}

\author{
Andreas Husch, Moritz Paehler, Debora Fusca, Lars Paeger, and Peter Kloppenburg \\ Institute of Zoology and Physiology, Center for Molecular Medicine Cologne, and Cologne Excellence Cluster on Cellular Stress Responses in Aging- \\ Associated Diseases, University of Cologne, 50931 Cologne, Germany
}

\begin{abstract}
Behavioral and physiological studies show that neuronal interactions among the glomeruli in the insect antennal lobe (AL) take place during the processing of odor information. These interactions are mediated by a complex network of inhibitory and excitatory local interneurons (LNs) that restructure the olfactory representation in the AL, thereby regulating the tuning profile of projection neurons. In Periplaneta americana, we characterized two LN types with distinctive physiological properties: (1) type I LNs that generated $\mathrm{Na}^{+}$-driven action potentials on odor stimulation and exhibited GABA-like immunoreactivity (GLIR) and (2) type II LNs, in which odor stimulation evoked depolarizations, but no $\mathrm{Na}^{+}$-driven action potentials (APs). Type II LNs did not express voltage-dependent transient $\mathrm{Na}^{+}$ currents and accordingly would not trigger transmitter release by $\mathrm{Na}^{+}$-driven APs. Ninety percent of type II LNs did not exhibit GLIR.

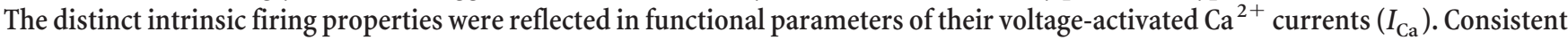
with graded synaptic release, we found a shift in the voltage for half-maximal activation of $I_{\mathrm{Ca}}$ to more hyperpolarized membrane potentials in the type II LNs. These marked physiological differences between the two LN types imply consequences for their computational capacity, synaptic output kinetics, and thus their function in the olfactory circuit.
\end{abstract}

Key words: antennal lobe; calcium currents; chemosensory; local interneurons; olfaction; projection neurons

\section{Introduction}

The ability to detect, process, and perceive complex odors is a significant evolutionary advantage. Complex neural circuits have evolved to accomplish this task with remarkable efficiency. The insect antennal lobe $(\mathrm{AL})$, the analog of the vertebrate olfactory bulb, is the first synaptic relay that processes olfactory information (for review, see Hildebrand and Shepherd, 1997; Strausfeld and Hildebrand, 1999; Davis, 2004; Wilson and Mainen, 2006; Vosshall and Stocker, 2007). The olfactory receptor neurons, each expressing a single functional receptor gene, send their axons to the AL, where they collate by receptor type and converge into specific glomeruli. In the glomeruli, they form synapses with projection neurons (PNs) and local interneurons (LNs). The PNs relay information to higher order neuropiles. The LNs mediate complex inhibitory and excitatory interactions between glomeruli to restructure the olfactory representation in the AL, which ultimately shapes the tuning profile of PNs (Wilson et al., 2004; Olsen et al., 2007; Shang et al., 2007; Olsen and Wilson, 2008).

Based on early immunohistochemical (Hoskins et al., 1986; Distler, 1989) and electrophysiological work (Waldrop et al., 1987; Christensen et al., 1993), LNs have historically been regarded as mostly GABAergic and inhibitory. In subsequent stud-

Received July 21, 2008; revised Dec. 4, 2008; accepted Dec. 10, 2008.

This work was supported by Deutsche Forschungsgemeinschaft Grant KI 762/4-1. We thank Helmut Wratil for excellent technical assistance and Bruce Johnson for valuable comments on previous versions of this manuscript.

Correspondence should be addressed to Peter Kloppenburg, Institute of Zoology and Physiology, University of Cologne, Weyertal 119, 50931 Cologne, Germany. E-mail: peter.kloppenburg@uni-koeln.de.

DOI:10.1523/JNEUROSCI.3677-08.2009

Copyright $\odot 2009$ Society for Neuroscience $\quad$ 0270-6474/09/290716-11\$15.00/0 ies, GABAergic LNs have been reported in various insect species (Schäfer and Bicker, 1986; Leitch and Laurent, 1996; Iwano and Kanzaki, 2005; Wilson and Laurent, 2005) and the importance of GABAergic, inhibitory LNs for odor information processing was clearly shown (Stopfer et al., 1997; Sachse and Galizia, 2002; Wilson and Laurent, 2005). In parallel, however, it became increasingly clear that the LNs are a more heterogeneous population of neurons than previously thought. In addition to GABA, they may also contain and release various peptides, biogenic amines (for review, see Homberg and Müller, 1999; Schachtner et al., 2005; Nässel and Homberg, 2006) and acetylcholine (Shang et al., 2007). Accordingly LNs can also be excitatory, as demonstrated recently (Olsen et al., 2007; Shang et al., 2007). Although odorinduced responses of LNs have been described in many insect species (Matsumoto and Hildebrand, 1981; Christensen et al., 1993; Sun et al., 1993; Hansson et al., 1994; Laurent and Davidowitz, 1994; Wilson and Laurent, 2005), relatively little is known about the heterogeneity in the intrinsic firing properties and the ionic mechanisms underlying these properties in LNs. Except in LNs of the locust, in which it has been suggested that depolarizations are driven by $\mathrm{Ca}^{2+}$ (Laurent, 1996), it was generally assumed that their action potentials (APs) were driven by $\mathrm{Na}^{+}$.

This study aims to better understand the intrinsic firing properties of LNs and the cellular mechanisms that determine them. In Periplaneta americana, we found two types of LNs with fundamentally different intrinsic firing properties, implying that these neurons serve distinct functions in the olfactory system: type I generated $\mathrm{Na}^{+}$-driven APs on odor stimulation. Type II could not generate $\mathrm{Na}^{+}$-driven APs and accordingly could not trigger synaptic release by APs. Consistent with graded transmitter re- 
lease, the voltage dependence for activation of $I_{\mathrm{Ca}}$ was shifted to more hyperpolarized membrane potentials in the type II LNs.

\section{Materials and Methods}

Animals and materials. P. americana were reared in crowded colonies at $27^{\circ} \mathrm{C}$ under a $13: 11 \mathrm{~h}$ light/dark photoperiod regimen, on a diet of dry rodent food, oatmeal, and water. The experiments were performed with adult males. All chemicals, unless stated otherwise, were obtained from Applichem or Sigma-Aldrich in "pro analysis" purity grade.

Intact brain preparation. The intact brain preparation was based on an approach described previously (Kloppenburg et al., 1999a,b), in which the entire olfactory system was left intact. The animals were anesthetized by $\mathrm{CO}_{2}$, placed in a custom-built holder and the head with antennae was immobilized with tape (Tesa Extrapower Gewebeband; Tesa). The head capsule was opened by cutting a window between the two compound eyes and the bases of the antennae. The brain with antennal nerves and antennae attached was dissected from the head capsule in "normal saline" (see below) and pinned in a Sylgard-coated (Dow Corning) recording chamber. To gain access to the recording site and facilitate the penetration of pharmacological agents into the tissue, we desheathed parts of the AL using fine forceps. Some preparations were also enzyme treated with a mixture of collagenase ( $8 \mathrm{U} \mathrm{ml}^{-1}$; LS004194; Worthington) and dispase $\left(0.7 \mathrm{U} \mathrm{ml}^{-1}\right.$; LS02100; Worthington) or a combination of papain (0.3 mg ml ${ }^{-1}$; P4762; Sigma-Aldrich) and L-cysteine ( $1 \mathrm{mg} \mathrm{ml}^{-1}$; 30090; Fluka) dissolved in normal saline [ $\sim 3 \mathrm{~min}$; room temperature (RT)]. For the recordings, the somata of the AL neurons were visualized with a fixed-stage upright microscope (BX51WI; Olympus) using a $40 \times$ waterimmersion objective [UMPLFL; 40×; 0.8 numerical aperture (NA); 3.3 $\mathrm{mm}$ working distance; Olympus] and infrared-differential interference contrast optics.

Whole-cell recordings. Whole-cell recordings were performed at $24^{\circ} \mathrm{C}$ following the methods described by Hamill et al. (1981). Electrodes with tip resistances between 3 and $5 \mathrm{M} \Omega$ were fashioned from borosilicate glass $[0.86 \mathrm{~mm}$ inner diameter (ID); $1.5 \mathrm{~mm}$ outer diameter (OD); GB150-8P; Science Products] with a temperature-controlled pipette puller (PIP5; HEKA). For current-clamp recordings, the pipettes were filled with normal intracellular saline solution containing the following (in mM): $190 \mathrm{~K}$-aspartate, $10 \mathrm{NaCl}, 1 \mathrm{CaCl}_{2}, 2 \mathrm{MgCl}_{2}, 10 \mathrm{HEPES}$, and 10 EGTA adjusted to pH 7.2 (with $\mathrm{KOH}$ ), resulting in an osmolarity of $\sim 415 \mathrm{mOsm}$. During the experiments, if not stated otherwise, the cells were superfused constantly with normal extracellular saline solution containing the following (in mM): $185 \mathrm{NaCl}, 4 \mathrm{KCl}, 6 \mathrm{CaCl}_{2}, 2 \mathrm{MgCl}_{2}, 10$ HEPES, and 35 D-glucose. The solution was adjusted to $\mathrm{pH} 7.2$ (with $\mathrm{NaOH}$ ) and to $430 \mathrm{mOsm}$ (with glucose). To isolate the $\mathrm{Ca}^{2+}$ currents, a combination of pharmacological blockers and ion substitution was used that has been shown to be effective in central olfactory neurons of the cockroach (Husch et al., 2008) and in other insect preparations (Schäfer et al., 1994; Kloppenburg and Hörner, 1998; Kloppenburg et al., 1999a). Transient voltage-gated $\mathrm{Na}^{+}$currents were blocked by tetrodotoxin (TTX) $\left(10^{-7}-10^{-4} \mathrm{M}\right.$; T-550; Alomone). 4-Aminopyridine (4-AP) $(4 \times$ $10^{-3} \mathrm{M}$; A78403; Aldrich) was used to block transient $\mathrm{K}^{+}$currents $\left(I_{\mathrm{A}}\right)$ and tetraethylammonium (TEA) $\left(2 \times 10^{-2} \mathrm{M}\right.$; T2265; Sigma-Aldrich) blocked sustained $\mathrm{K}^{+}$currents $\left(I_{\mathrm{K}(\mathrm{V})}\right)$ as well as $\mathrm{Ca}^{2+}$-activated outward currents $\left(I_{\mathrm{O}(\mathrm{Ca})}\right)$. To compensate for changes in osmolarity, the glucose concentration was appropriately reduced. In the pipette solution, $\mathrm{K}$-aspartate was substituted with $\mathrm{CsCl}$ to eliminate unblocked $\mathrm{K}^{+}$currents. The effects of the blockers on the whole-cell currents are demonstrated in supplemental Figure 1 (available at www.jneurosci.org as supplemental material).

Whole-cell voltage- and current-clamp recordings were performed with an EPC9 patch-clamp amplifier (HEKA) controlled by the program Pulse (version 8.63, HEKA) running under Windows. Most electrophysiological data were sampled at intervals of $100 \mu \mathrm{s}(10 \mathrm{kHz})$; tail currents were sampled at $20 \mathrm{kHz}$. The recordings were low-pass filtered at $2 \mathrm{kHz}$ with a four-pole Bessel filter. Compensation of the offset potential and capacitive currents was performed using the "automatic mode" of the EPC9 amplifier. Whole-cell capacitance was determined by using the capacitance compensation (C-slow) of the EPC9. Cell input resistances $\left(R_{\mathrm{M}}\right)$ were calculated from voltage responses to hyperpolarizing current pulses. The calculated liquid junction potential between intracellular and extracellular solution was also compensated [ $15.4 \mathrm{mV}$ for "normal" and $4.8 \mathrm{mV}$ for "calcium" extracellular/intracellular saline; calculated with Patcher's-Power-Tools plug-in from http://www.mpibpc.gwdg.de/ abteilungen/140/software/index.html for Igor Pro (Wavemetrics)]. To remove uncompensated leakage and capacitive currents, a p/6 protocol was used (Armstrong and Bezanilla, 1974). Voltage errors caused by series resistance $\left(R_{\mathrm{S}}\right)$ were minimized using the $R_{\mathrm{S}}$ compensation of the EPC9. $R_{\mathrm{S}}$ was compensated between 50 and $70 \%$ with a time constant $(\tau)$ of $2 \mu$ s. Stimulus protocols used for each set of experiments are provided in Results.

Steady-state tail current activation and steady-state inactivation data were fit with a first-order $(n=1)$ Boltzmann equation of the following form:

$$
\frac{I}{I_{\max }}=\frac{1}{\left(1+e^{\left(V_{0.5}-V\right) / s}\right)^{n}} .
$$

$I_{\max }$ is the maximal current, $V$ is the voltage of the test pulse, $I$ is the current at voltage $V, s$ is the slope factor, and $V_{0.5}$ is the voltage at which half-maximal activation or inactivation occurs.

We used the software Pulse (version 8.63; HEKA), Igor Pro 4 (Wavemetrics; including the Patcher's PowerTools plug-in), and R (http:// www.r-project.org) for analysis of electrophysiological data. All calculated values are expressed as mean $\pm \mathrm{SD}$. To determine differences in means between the different cell types, ANOVA was performed; post hoc pairwise comparisons were performed using $t$ tests with the Holm method for $p$ value adjustment. A significance level of 0.05 was accepted for all tests.

Odor stimulation. We delivered odors using a continuous air flow system. Carbon-filtered, humidified air flowed continuously across the antennae at a rate of $21 \mathrm{~min}^{-1}$ ("main airstream") through a glass tube (10 mm ID) placed perpendicular to and within $20-30 \mathrm{~mm}$ of the antennae. Odors were quickly removed with a vacuum funnel $(3.5 \mathrm{~cm} \mathrm{ID})$ placed $5 \mathrm{~cm}$ behind the animal. Five milliliters of the liquid odorants [pure or diluted in mineral oil (M8410; Sigma-Aldrich)] were filled in $100 \mathrm{ml}$ glass vessels. During a $500 \mathrm{~ms}$ odor stimulus, $22.5 \mathrm{ml}$ of the headspace was injected into the airstream. To ensure a continuous air flow volume across the preparation, the air delivering the odor was redirected from the main airstream by a solenoid valve system. The solenoids were controlled by the D/A-interface of the EPC9 patch-clamp amplifier and the Pulse software. The odorants were adjusted with mineral oil to a final volume of $5 \mathrm{ml}$. The concentration was adjusted to the odorant with the lowest vapor pressure (eugenol). Stripes of filter paper were used to facilitate evaporation. Dilutions were as follows: eugenol, 100\% (E51791; Aldrich); $\alpha$-ionone, 72.4\% (I12409; Aldrich); +/- citral, $14.6 \%$ (C83007; Aldrich); citronellal, 4.9\% (W230715; Sigma-Aldrich). The headspace of pure mineral oil was used as control stimulus (blank). Odor stimuli arrived at least $60 \mathrm{~s}$ apart.

Single-cell labeling. To label single cells, 1\% biocytin (B4261; SigmaAldrich) was added to the pipette solution. After the recordings, the brains were fixed in Roti-Histofix (P0873; Carl Roth) overnight at $4^{\circ} \mathrm{C}$ and rinsed in $0.1 \mathrm{M}$ Tris-HCl-buffered solution (TBS), pH 7.2 (three times for $10 \mathrm{~min}$ each time). To facilitate the streptavidin penetration, the brains were treated with a commercially available collagenase/dispase mixture ( $1 \mathrm{mg} \mathrm{ml}^{-1}$; 269638; Roche Diagnostics) and hyaluronidase (1 $\mathrm{mg} \mathrm{ml}{ }^{-1}$; H3506; Sigma-Aldrich) in TBS $\left(20 \mathrm{~min} ; 37^{\circ} \mathrm{C}\right)$, rinsed in TBS (three times for $10 \mathrm{~min}$ each time; $4^{\circ} \mathrm{C}$ ) and incubated in TBS containing $1 \%$ Triton X-100 (30 min; RT; Serva). Afterward, the brains were incubated in Alexa Fluor 633 (Alexa 633)-conjugated streptavidin (1:600; 1-2 d; $4^{\circ} \mathrm{C}$; S21375; Invitrogen) that was dissolved in TBS containing $10 \%$ normal goat serum (S-1000; Vector Labs). Brains were rinsed in TBS (three times for 10 min each time; $4^{\circ} \mathrm{C}$ ), dehydrated, and then cleared and mounted in methylsalicylate (M6752; Sigma-Aldrich).

GABA immunohistochemistry and double labeling. After loading the cell with biocytin, the brains were fixed in PGA (picric acid-glutaraldehydeacetic acid) (overnight; $4^{\circ} \mathrm{C}$ ), containing 3 fractions of saturated picric acid (A2520; AppliChem), 1 fraction of 25\% glutaraldehyde (A0589; AppliChem), and 0.02 fractions of acetic acid (A3701; AppliChem). Sub- 
sequently, the brains were rinsed in phosphate-buffered solution (PBS), pH 7.2 (three times for 20 min each time and overnight, RT), dehydrated, treated with xylene for 5-10 min to remove lipids, and rehydrated (PBS; three times for 10 min each time). To facilitate the antibody penetration, the brain was enzyme treated $\left(1 \mathrm{mg} \mathrm{ml}^{-1}\right.$ collagenase/dispase and $1 \mathrm{mg}$ $\mathrm{ml}^{-1}$ hyaluronidase in PBS; $1 \mathrm{~h} ; 37^{\circ} \mathrm{C}$ ), rinsed in PBS (three times for 10 min each time; $4^{\circ} \mathrm{C}$ ), and incubated in PBS containing $1 \%$ Triton X-100 (PBS-1\% Tx) (2 h; RT). The preparations were then preincubated in blocking solution (overnight; $4^{\circ} \mathrm{C}$ ) containing $5 \%$ normal goat serum, $0.25 \%$ bovine serum albumin (A1391; AppliChem), 3\% skim milk powder (Heirler Cenovis), $0.1 \% \mathrm{Na}^{+}$azide (S2002; Sigma-Aldrich), and $0.5 \%$ Triton X-100 to block unspecific antibody binding. The brains were incubated for 1 week $\left(4^{\circ} \mathrm{C}\right)$ in blocking solution containing polyclonal rabbit anti-GABA primary antibody (1:750; A2052; Sigma-Aldrich), rinsed in PBS-1\% Tx $\left(10 \mathrm{~min} ; 4^{\circ} \mathrm{C}\right.$ ) and PBS-0.5\% Tx (two times for $2 \mathrm{~h}$ each time; $4^{\circ} \mathrm{C}$ ), and incubated in Cy2-conjugated goat anti-rabbit IgG $(\mathrm{H}+\mathrm{L})$ secondary antibody $\left(1: 200 ; 6 \mathrm{~d} ; 4^{\circ} \mathrm{C} ; 111-225-003\right.$; Dianova $)$ dissolved in blocking solution. After rinsing in PBS-1\% Tx (two times for 10 min each time; $4^{\circ} \mathrm{C}$ ), PBS- $0.5 \% \mathrm{Tx}$ (two times for $2 \mathrm{~h}$ each time; $4^{\circ} \mathrm{C}$ ), and PBS (three times for $10 \mathrm{~min}$ each time; $4^{\circ} \mathrm{C}$ ), the brains were incubated in Alexa 633-conjugated streptavidin (1:600) and 10\% normal goat serum (in PBS; overnight; $4^{\circ} \mathrm{C}$ ), rinsed in PBS (three times for $10 \mathrm{~min}$ each time; $4^{\circ} \mathrm{C}$ ), dehydrated, and then cleared and mounted in methylsalicylate. All staining was abolished with preadsorption of the primary antibody with $10^{-3} \mathrm{M}$ GABA. Details of the antibody development and its specificity are provided in the product information (A2052; Sigma-Aldrich).

Sectioning and microscopy. After taking images of the whole-mount preparations, the brains were rinsed in $100 \%$ ethanol for $10 \mathrm{~min}$ to remove the methylsalicylate, rehydrated, and rinsed in TBS or PBS $(3 \times 10$ $\mathrm{min}$ ). The brains were embedded in agarose (4\% in TBS or PBS; 11380 ; Serva) and $100 \mu \mathrm{m}$ frontohorizontal sections were cut in TBS or PBS with a vibratome (Leica VT1000 S). The slices were rinsed in $\mathrm{H}_{2} \mathrm{O}$, dried on coated slides $[0.05 \%$ chrome-alum (60151; Fluka/Sigma-Aldrich) and $0.5 \%$ gelatin (4078; Merck)], treated with xylene for $10 \mathrm{~min}$, and mounted in Permount (SP15B; Thermo Fisher Scientific).

The fluorescence images were captured with a confocal microscope (LSM 510; Carl Zeiss) equipped with Plan-Neofluar $10 \times(0.3$ NA), PlanApochromat $20 \times(0.75 \mathrm{NA})$, and Plan-Apochromat $63 \times(1.4 \mathrm{NA}$ oil $)$ objectives. Streptavidin-Alexa 633 and Cy2 were imaged with 633 and $488 \mathrm{~nm}$ excitation, respectively. Emission of Alexa 633 and Cy2 was collected through a 650 and $505 \mathrm{~nm}$ LP filter, respectively. The multitrack mode of the LSM 510 was used for double labeling. For overviews, overlapping stacks $(10 \times)$ were acquired and merged using the photomerge function in Photoshop CS2 (Adobe Systems). Confocal images of double-labeled preparations were adjusted for contrast and brightness and overlaid in Photoshop CS2. Calibration, noise reduction, and $z$-projections were done using ImageJ, version $1.35 \mathrm{~d}$, with the WCIF plugin bundle (www.uhnresearch.ca/facilities/wcif/).

\section{Results}

The focus of this study was a comparison of voltage-activated $\mathrm{Ca}^{2+}$ currents in two physiologically and morphologically different subtypes of LNs. An important prerequisite for this project was an unequivocal classification and identification of the different LN types. Accordingly, we will describe in the first part the physiological and morphological characteristics by which we differentiated the LNs, some of which have not been described in $P$. americana or in other insects in detail previously. In parallel, we will present, as a reference, data from uniglomerular projection neurons ( $\mathrm{uPNs}$ ). Projection neurons generate $\mathrm{Na}^{+}$-driven action potentials, and their morphology and response properties are well known in the cockroach (Burrows et al., 1982; Ernst and Boeckh, 1983; Boeckh and Ernst, 1987; Malun et al., 1993; Distler and Boeckh, 1997a) and other insects [Apis mellifera (Sun et al., 1997; Abel et al., 2001), Drosophila melanogaster (Wilson et al., 2004), Schistocerca americana (Wehr and Laurent, 1996; Stopfer and Laurent, 1999; Stopfer et al., 2003; Bazhenov et al., 2005; Broome et al., 2006), and different moths (Waldrop et al., 1987; Kanzaki et al., 1989; Hansson et al., 1994; Masante-Roca et al., 2005; Namiki et al., 2008)]. In the second part, we present a detailed analysis of the voltage-activated $\mathrm{Ca}^{2+}$ currents in two physiologically different LN types and uPNs.

\section{Classification and identification of neurons}

\section{Overview}

Whole-cell patch-clamp recordings were performed under visual control from cell bodies in the ventrolateral somata group (VSG) (Distler et al., 1998). The large majority of cell bodies in the ventral portion of the VSG belong to a relatively homogeneous cluster of uniglomerular projection neurons sending their axons along the inner antenno-cerebral tract (IACT) (Malun et al., 1993). Somata situated in the dorsal portion of the VSG were mostly LN cell bodies of various sizes. These LNs were not a homogeneous group and differed markedly in their morphology and physiological properties.

In this study, we based the physiological and morphological classification of neurons on the following properties: responses to a set of four odors $(+/-$ citral, citronellal, eugenol, and $\alpha$-ionone), intrinsic firing properties determined by current injection protocols, whole-cell current profiles, and morphological features including branching patterns and GABA-like immunoreactivity (GLIR). Using these criteria, we differentiated three types of central olfactory interneurons: (1) uniglomerular projection neurons, (2) type I local interneurons, and (3) type II local interneurons. Odor stimulation generated $\mathrm{Na}^{+}$-driven action potentials in uPNs. These neurons receive synaptic input in one glomerulus and project to the mushroom bodies and to the lateral lobe of the protocerebrum. Type I LNs also generated $\mathrm{Na}^{+}$driven action potentials. They had arborizations in many, but not all glomeruli. The density of processes varied between glomeruli of a given type I LN. Type II LNs did not generate $\mathrm{Na}^{+}$-driven action potentials and had apparently processes in all glomeruli, whereas the density and distribution of arborizations was similar in all glomeruli of a given type II LN. However, the density and distribution of processes varied between different type II LNs.

This study is based on recordings and subsequent single-cell labeling of 75 central olfactory neurons ( 25 uPNs, 21 type I LNs, 29 type II LNs). The electrophysiological parameters of all three neuron types are summarized in supplemental Table 1 (available at www.jneurosci.org as supplemental material). It is important to emphasize that an additional analysis of physiological and morphological properties of the two LN types might reveal more neuronal subtypes.

\section{$u P N s$}

All recorded uPNs generated $\mathrm{Na}^{+}$-driven action potentials on stimulation with odors or depolarizing current injection (Figs. $1 A, B, 2 A, B)$. As long as the antenna and antennal nerve were intact, uPNs received abundant synaptic input, mostly EPSPs (Figs. $1 A, B, 2 A, B)$. A given $\mathrm{uPN}$ can respond to odorants of many different chemical classes, often with odor-specific elaborate patterns of excitation and spiking that could also include periods of inhibition (Fig. $1 A, B$ ). These response patterns can vary for different odorants (Fig. $1 A$ ), but are reproducible between stimulations with the same odorant (Fig. $1 B$ ). The blank stimulus did not evoke detectable responses (Fig. $1 A$ ). In voltage clamp without channel blockers, depolarizing voltage steps from a holding potential of $-80 \mathrm{mV}$ evoked a transient, TTX-sensitive $\mathrm{Na}^{+}$current followed by transient, 4-AP-sensitive and sustained, 
A A1 UPN $\alpha$-ionone

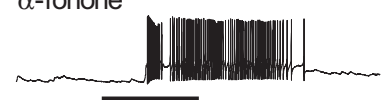

+ - citral

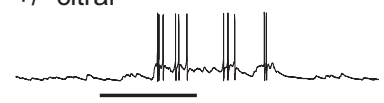

citronellal
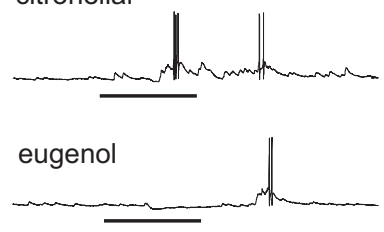

blank

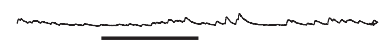

B

B1

UPN
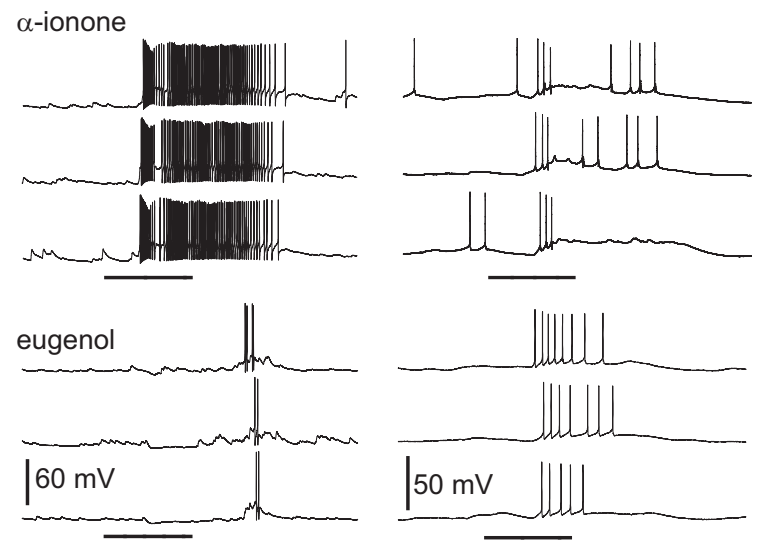

A2

type I LN
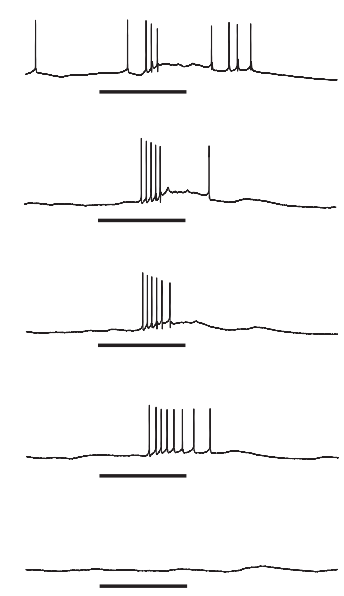

B2

type I LN

\section{B3}

type II LN
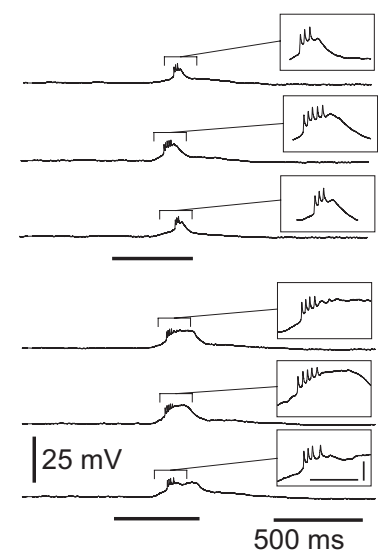

Figure 1. Typical odor responses from different classes of central AL neurons. $\boldsymbol{A}$, Whole-cell patch-clamp recordings of a uPN, a type I LN, and a type II LN during odor stimulation with four different odorants and a blank stimulus. A1, The uPN responded to the different odorants with odor-specific patterns of excitation and spiking that could include periods of inhibition. $\mathbf{A 2}$, The type I LN responded to all presented odors with excitation and $\mathrm{Na}^{+}$-driven action potentials. $\mathbf{A}$, The type II LN reacted to all presented odorants with graded depolarization, but never with overshooting $\mathrm{Na}^{+}$-driven action potentials. In $\sim 30 \%$ of the recorded type II LNs not $\mathrm{Na}^{+}$driven, spikelets have been observed on top of the depolarizations. All neuron types did not respond to the blank stimulation. $\boldsymbol{B}$, Consistency of responses from the same neurons as in $\boldsymbol{A}$ to repetitive stimulation with the same odorant. Intervals between odor stimulations were at least $1 \mathrm{~min}$. Typically the responses to repeated stimulations with the same odorant were more consistent in uPNs (B1) compared with local interneurons of both types $(\boldsymbol{B} 2, \boldsymbol{B} 3)$. The horizontal bars beneath the recordings mark the duration of the odor stimulation ( $500 \mathrm{~ms}$; valve open). Calibration: $A 3, B 3$, insets, $100 \mathrm{~ms}, 5 \mathrm{mV}$.

TEA-sensitive $\mathrm{K}^{+}$currents (Fig. $2 C$ ). Uniglomerular projection neurons had a membrane potential $\left(E_{\mathrm{M}}\right)$ of $-61.4 \pm 9.1 \mathrm{mV}(n=$ $14)$, a cell input resistance $\left(R_{\mathrm{M}}\right)$ of $89.6 \pm 39.2 \mathrm{M} \Omega(n=11)$, and a whole-cell membrane capacitance $\left(C_{\mathrm{M}}\right)$ of $22.9 \pm 9.3 \mathrm{pF}(n=$ 15). Single-cell labeling of each recorded neuron confirmed that all neurons recorded in the ventral portion of the VSG were uPNs (Fig. 2D,E). Each of the uPNs had arborizations in a single glomerulus and sent a single axon through the IACT to the protocerebrum (Malun et al., 1993), innervating the mushroom body calyces and the lateral lobe of the protocerebrum (Fig. 2E). We did not detect GLIR in the ventral part of the VSG (data not shown), confirming previous work, which showed that uPNs are not GABAergic (Distler, 1989).

LNs

Typically, LNs responded to all tested odors. Based on their response characteristics to odors, their intrinsic firing properties, and morphological features, we differentiated two major types of LNs that we refer to as type I and type II LNs. The principal physiological difference was that type I LNs generated $\mathrm{Na}^{+}$-driven action potentials on depolarizing current injections or stimulation with odors, whereas type II LNs did not.

Type I LNs

Type I LNs generated $\mathrm{Na}^{+}$-driven action potentials on depolarizing current injections or odor stimulation (Figs. $1 A, B$, $3 A, B)$. Generally, type I LNs were broadly tuned like the uPNs and each responded to different odorants more similarly than the uPNs (Fig. 1A). The responses were reproducible between repeated stimulations with the same odorant, but with greater response variability than the uPNs (Fig. $1 B)$. In voltage clamp without channel blockers, depolarizing voltage steps from a holding potential of $-80 \mathrm{mV}$ evoked a transient TTX-sensitive $\mathrm{Na}^{+}$current followed by a transient 4-AP-sensitive and a sustained TEA-sensitive $\mathrm{K}^{+}$current (Fig. 3C). Type I LNs had a membrane potential $\left(E_{\mathrm{M}}\right)$ of $-53.0 \pm 7.4 \mathrm{mV}(n=16)$, a cell input resistance $\left(R_{\mathrm{M}}\right)$ of $50.6 \pm 22.3 \mathrm{M} \Omega$ $(n=13)$, and a whole-cell membrane capacitance $\left(C_{\mathrm{M}}\right)$ of $36.8 \pm 16.3 \mathrm{pF}(n=19)$. Type I LNs had arborizations in many, but not all glomeruli (Fig. 3D,E). Many of the type I LNs had arborizations in the macroglomerulus (MG) (Fig. 3E $E_{1}$ ). The density of neurites varied between glomeruli of a given neuron (Fig. 3D,E). Five preparations with single biocytin-labeled type I LNs were immunolabeled with antibodies against GABA and in all preparations the type I LNs clearly exhibited GLIR (Fig. 3F). All of the neurons containing GLIR gave rise to the $y$-shaped tract (YST) (Fig. 3E,F), in agreement with previous studies (Distler, 1989; Distler and Boeckh, 1997b).

\section{Type II LNs}

Neither odor stimulation nor depolarizing current injection induced $\mathrm{Na}^{+}$-driven action potentials in type II LNs (Figs. $1 A, B$, $4 B, C)$, in clear contrast to the responses of uPNs and type I LNs. Odor stimulations induced sustained membrane depolarizations, in $\sim 30 \%$ of the recordings with "spikelets" $(\sim 2 \mathrm{mV}$; not $\mathrm{Na}^{+}$driven) riding on the depolarizations (Figs. $1 A, B, 4 B$ ). We never detected fast transient TTX-sensitive $\mathrm{Na}^{+}$currents in voltage clamp even when all other voltage-activated currents were blocked to make the neuron electrotonically more compact (data not shown) (Yuste et al., 1994; Kloppenburg et al., 2000). Voltage 
uniglomerular projection neuron
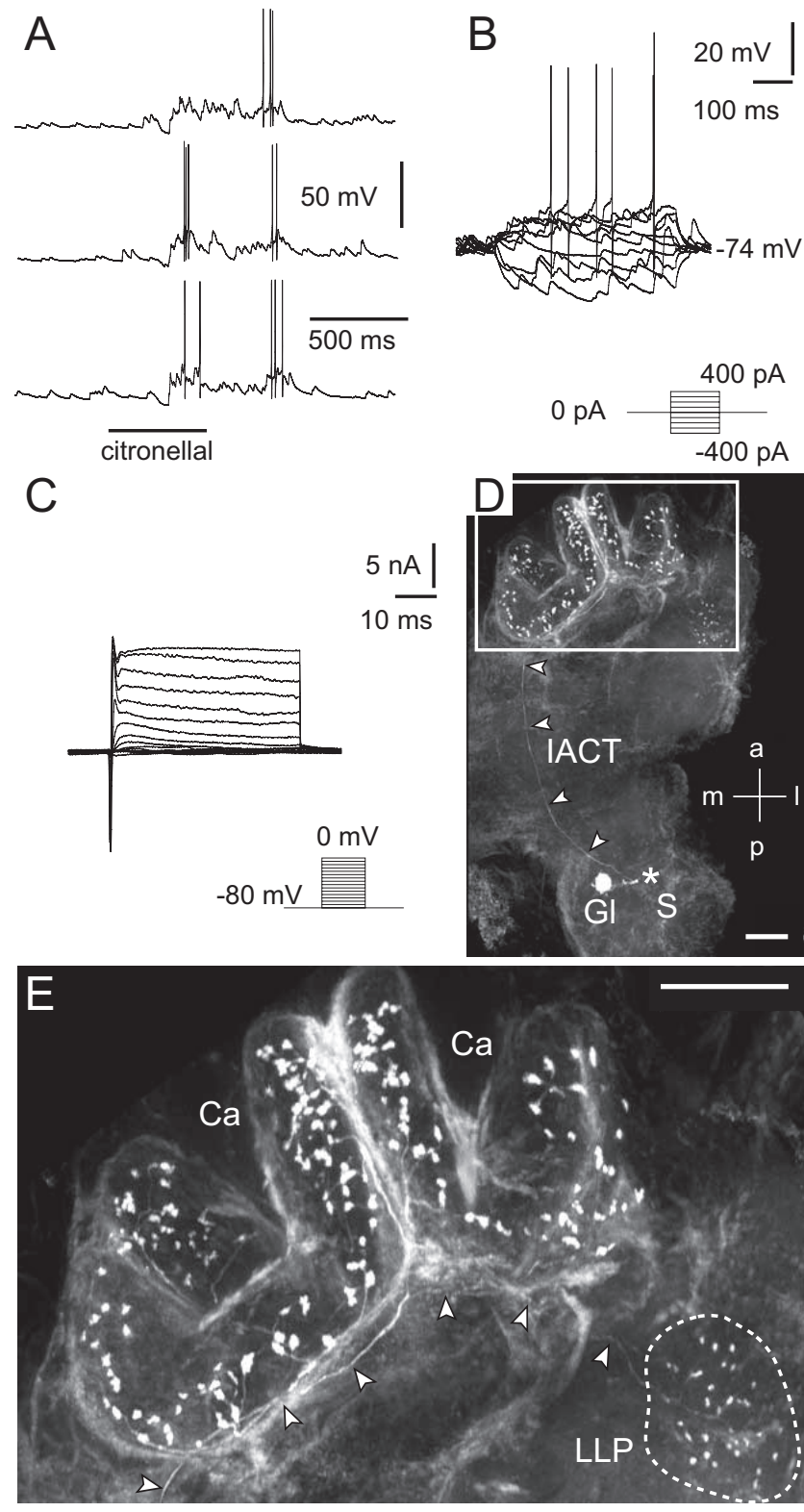

Figure 2. uPN: electrophysiological and morphological characteristics. $\boldsymbol{A}, \boldsymbol{B}, 0$ dor stimulation $(\boldsymbol{A})$ and injection of depolarizing current $(\boldsymbol{B})$ induced overshooting action potentials. Current was injected for $500 \mathrm{~ms}$ from -400 to $400 \mathrm{pA}$ in 100 pA steps. C, Whole-cell recordings of (mainly) voltage-activated currents in normal saline. Depolarizing voltage steps from a holding potential of $-80 \mathrm{mV}$ elicited a fast transient inward current followed by transient and more sustained outward currents. Both the inward and outward currents consisted of several ionic currents in combination. By using ion substitution, standard pharmacological agents, and appropriate voltage protocols, several components of the inward and outward currents were identified. The transient, fast activating/inactivating inward current was a TTX-sensitive $\mathrm{Na}{ }^{+}$ current. A smaller, more sustained inward $\mathrm{Ca}^{2+}$ current was masked by large outward currents. The outward currents consisted of at least three components: (1) a transient, 4-AP-sensitive, voltage-dependent current $\left(I_{A}\right) ;(2)$ a more sustained, TEA-sensitive, voltage-dependent current $\left(I_{\mathrm{K}(\mathrm{V})}\right)$; and (3) a voltage- and $\mathrm{Ca}^{2+}$-dependent, TEA-sensitive outward current $\left(I_{0(\mathrm{Ca})}\right) . \boldsymbol{D}$, $\boldsymbol{E}$, Morphology of the recorded neuron revealed by staining via the patch pipette (360 $\mu \mathrm{m}$ image stack). $D$, The position of the soma $(S)$, which was lost during processing, is marked $\left({ }^{*}\right)$. The neuron innervated a single glomerulus and sent a single axon along the IACT (arrowheads) to the mushroom body's calyces (Ca) and the lateral lobe of the protocerebrum (LLP). $\boldsymbol{E}$, Higher magnification of the framed area from $\boldsymbol{D}$ showing boutons of the UPN in the calyces and an axon (arrowheads) that terminates in boutons innervating the LLP (outlined by dotted line). a, Anterior; $C a$, calyces; $G$ l, glomerulus; I, lateral; LLP, lateral lobe of the protocerebrum; $m$, medial; $p$, posterior; S, soma. Scale bars: $\boldsymbol{D}, \boldsymbol{E}, 100 \mu \mathrm{m}$. steps to between -55 and $-25 \mathrm{mV}$ from a holding potential of $-80 \mathrm{mV}$ revealed a sustained inward current identified as a voltage-activated $\mathrm{Ca}^{2+}$ current (Fig. $4 D$ ). This observation is remarkable because in most neuron types the voltage-activated $\mathrm{Ca}^{2+}$ currents are masked by large outward $\mathrm{K}^{+}$currents in absence of $\mathrm{K}^{+}$channel blockers (Schäfer et al., 1994; Kloppenburg and Hörner, 1998; Benkenstein et al., 1999; Kloppenburg et al., 1999a). These $\mathrm{Ca}^{2+}$ currents were of relatively large amplitude and are described in more detail below. Greater depolarizing voltage steps to between -20 and $0 \mathrm{mV}$ evoked dominating outward $\mathrm{K}^{+}$currents with 4-AP- and TEA-sensitive components (Fig. $4 D, E$ ). In most recordings, the outward current oscillated at the beginning of the voltage step (Fig. $4 D, E$ ). These oscillations were insensitive to high concentrations of TTX $\left(10^{-4} \mathrm{M}\right)$, but were blocked by $\mathrm{Cd}^{2+}\left(5 \times 10^{-4} \mathrm{M}\right)$ (Fig. $\left.4 E\right)$, indicating that they were generated by the interplay of outward $\mathrm{K}^{+}$and inward $\mathrm{Ca}^{2+}$ currents in regions of the neuron without perfect voltage control. Note that the neurons are electrotonically not very compact when no channel blockers are applied (Yuste et al., 1994; Kloppenburg et al., 2000). Type II LNs had a membrane potential $\left(E_{\mathrm{M}}\right)$ of $-56.9 \pm 11.3 \mathrm{mV}(n=24)$, a cell input resistance $\left(R_{\mathrm{M}}\right)$ of $37.6 \pm 14.9 \mathrm{M} \Omega(n=22)$, and a whole-cell membrane capacitance $\left(C_{\mathrm{M}}\right)$ of $87.7 \pm 38.7 \mathrm{pF}(n=29)$. Type II LNs had apparently arborizations in all glomeruli including the MG, whereas the density and distribution of processes were similar in all glomeruli of a given neuron (Fig. 4A,F). However, the density and distribution of branches varied between different neurons. Only one of 10 tested type II LNs exhibited GLIR.

\section{Characteristics of voltage-activated $\mathrm{Ca}^{2+}$ currents $\left(I_{\mathrm{Ca}}\right)$ in different cell types}

We used whole-cell voltage-clamp recordings to characterize voltage-activated $\mathrm{Ca}^{2+}$ currents in unequivocally classified uPNs, type I LNs, and type II LNs that were identified by the parameters described above. The aim was to test whether the distinct physiology of these different neuron types was reflected in the functional properties of their $\mathrm{Ca}^{2+}$ currents. The quantitative characterization and comparison of $I_{\mathrm{Ca}}$ between the different neuron types was based on a set of parameters including amplitude, voltage dependence, and current density (Fig. 5). When all other currents were reduced by ion substitution and pharmacological reagents, we recorded inward currents that were identified previously as voltage-activated $\mathrm{Ca}^{2+}$ currents (Husch et al., 2008). To characterize $I_{\mathrm{Ca}}$ here, the neurons were superfused with saline containing $10^{-7}-10^{-4} \mathrm{M}$ TTX, $4 \times 10^{-3} \mathrm{M}$ 4-AP, and $2 \times 10^{-2} \mathrm{M}$ TEA. In the pipette solution $\mathrm{K}^{+}$was replaced with $\mathrm{Cs}^{+}$. The membrane potential was clamped at -80 $\mathrm{mV}$.

The current/voltage $(I-V)$ relationship of the peak $I_{\mathrm{Ca}}$ was determined by voltage steps between -80 and $40 \mathrm{mV}$ in $5 \mathrm{mV}$ increments (Fig. $5 A, B$ ). The voltage dependence for activation of $I_{\mathrm{Ca}}$ was determined from tail currents, which are independent of the changing driving force during a series of varying voltage pulses. Tail currents were evoked by $5 \mathrm{~ms}$ voltage steps between -80 and $50 \mathrm{mV}$ in $10 \mathrm{mV}$ increments (Fig. $5 C, D$ ). The $I-V$ relationships of the tail current peaks were fit to a first-order Boltzmann relationship (Eq. 1) (Fig. 5D). To measure steady-state inactivation, $500 \mathrm{~ms}$ prepulses were delivered in $5 \mathrm{mV}$ increments from -95 to $-5 \mathrm{mV}$, followed by a test pulse to $-5 \mathrm{mV}$, and the peak currents were determined (supplemental Fig. 2, available at www.jneurosci.org as supplemental material). The $I-V$ curves were fit to a first-order Boltzmann equation (Eq. 1). During depolarizing voltage steps, $I_{\mathrm{Ca}}$ activated relatively quickly and de- 


\section{type I local interneuron}
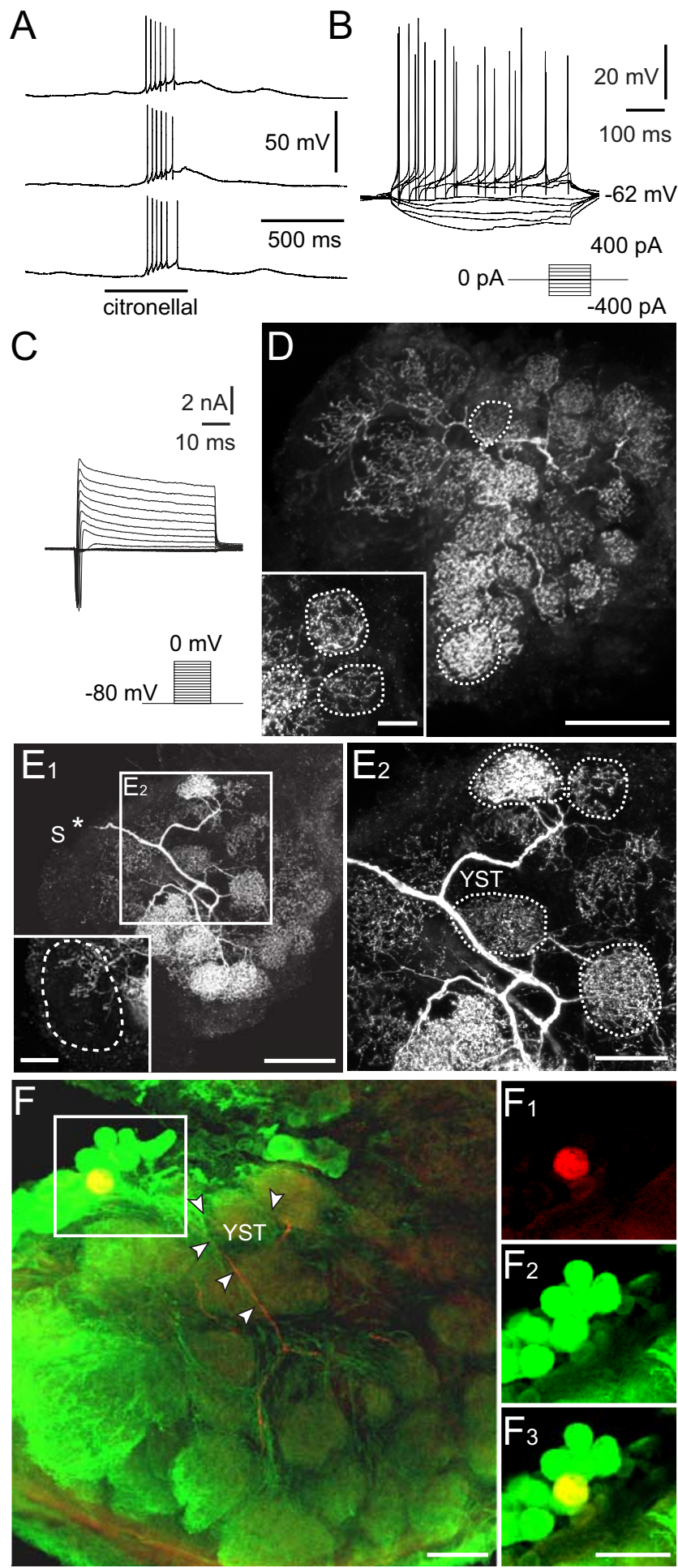

Figure 3. Type I LN: electrophysiological and morphological characteristics. $A, B, 0$ dor stimulation $(\boldsymbol{A})$ and injection of depolarizing current $(\boldsymbol{B})$ induced overshooting action potentials. Current was injected for $500 \mathrm{~ms}$ from -400 to $400 \mathrm{pA}$ in $100 \mathrm{pA}$ steps. C, Whole-cell recordings of (mainly) voltage-activated currents in normal saline. Depolarizing voltage steps from a holding potential of $-80 \mathrm{mV}$ elicited a fast transient inward current followed by a transient and more sustained outward currents. As in uPNs (Fig. 2), the transient, fast activating/inactivating inward current was a TTX-sensitive $\mathrm{Na}^{+}$current. A smaller, more sustained inward $\mathrm{Ca}^{2+}$ current was masked by large outward $\mathrm{K}^{+}$currents. The outward currents consisted of at least three currents: $I_{A} I_{K(V)}$ and $I_{O(C a)}$. D, Morphology of the recorded neuron (110 $\mu$ m image stack). The position of the soma was not in the image stack. The neuron innervated many, but not all, cayed during a maintained voltage step in all three cell types (Fig. $5 A$ ). The activation and inactivation kinetics during a voltage step were voltage dependent. The time to peak current and the time constant for the decay during a voltage pulse decreased with voltage steps of increasing amplitude. The current waveforms and physiological properties were typical for $I_{\mathrm{Ca}}$, but varied between cell types (Fig. 5A).

$\mathrm{I}_{\mathrm{Ca}}$ in $\mathrm{uPNs}$

In $\mathrm{uPNs}, I_{\mathrm{Ca}}$ started to activate with voltage steps more depolarized than $-35 \mathrm{mV}$ (Fig. 5A,B). The peak current reached its maximum amplitude $\left(I_{\mathrm{Ca}_{\max }}\right)$ of $1.4 \pm 0.4 \mathrm{nA}$ at $5.8 \pm 4.9 \mathrm{mV}(n$ $=12$ ) (Fig. $5 B$ ) and decreased during more positive test pulses as these currents approached the $\mathrm{Ca}^{2+}$ equilibrium potential (Fig. $5 A, B$ ). The $I-V$ relationship of the tail currents (Fig. $5 C, D$ ) had a voltage for half-maximal activation $\left(V_{0.5_{\text {act }}}\right)$ of $-10.6 \pm 3.4 \mathrm{mV}$ $\left(s_{\text {act }}=8.5 \pm 1.8 ; n=12\right.$ ) (Fig. $\left.5 D\right)$. The maximum amplitude of the tail currents $\left(I_{\mathrm{Ca}, \text { tail }}\right)$ determined from Boltzmann fits was $2.1 \pm 0.6 \mathrm{nA}(n=12)$, which corresponded to a maximal conductance $\left(G_{\max }\right)$ of $16.1 \pm 4.7 \mathrm{nS}$. Given a mean whole-cell capacitance $\left(C_{\mathrm{M}}\right)$ of $26.4 \pm 9.5 \mathrm{pF}(n=12)$, this corresponded to a current density $\left(I_{\mathrm{Ca} \text {,tail }}{ }_{\max } C_{\mathrm{M}}{ }^{-1}, I_{\mathrm{Ca} \text {,tail }}{ }_{\max } A_{\mathrm{M}}{ }^{-1}\right)$ of $89.0 \pm 33.7 \mathrm{pA}$ $\mathrm{pF}^{-1}\left(0.9 \pm 0.3 \mathrm{pA} \mathrm{\mu m}^{-2}\right)$ and a conductance density of $657.5 \pm$ $252.9 \mathrm{pS} \mathrm{pF}^{-1}\left(6.6 \pm 2.5 \mathrm{pS} \mu \mathrm{m}^{-2}\right)$. Steady-state inactivation (supplemental Fig. 2, available at www.jneurosci.org as supplemental material) started at prepulse potentials around $-55 \mathrm{mV}$ and increased with the amplitude of the depolarizing prepulse. The $I-V$ relationship had a voltage for half-maximal inactivation $\left(V_{0.5_{\text {inact }}}\right)$ of $-29.6 \pm 4.0 \mathrm{mV}\left(s_{\text {inact }}=8.4 \pm 0.5 ; n=12\right)$.

$\mathrm{I}_{\mathrm{Ca}}$ in type I LNs

$I_{\mathrm{Ca}}$ recorded in type I LNs started to activate with voltage steps more depolarized than $-50 \mathrm{mV}$ (Fig. $5 A, B$ ). The peak current reached its maximum amplitude $\left(I_{\mathrm{Ca}_{\max }}\right)$ of $1.0 \pm 0.3 \mathrm{nA}$ at $9.0 \pm$ $6.1 \mathrm{mV}(n=10)$ (Fig. $5 B)$. The Boltzmann analysis of the tail currents (Fig. 5C,D) revealed a voltage for half-maximal activation $\left(V_{0.5_{\text {act }}}\right)$ of $-11.1 \pm 6.5 \mathrm{mV}\left(s_{\text {act }}=10.0 \pm 2.3 ; n=10\right)$ (Fig. $5 D)$ and a maximum amplitude of $1.4 \pm 0.6 \mathrm{nA}(n=10)$, which corresponded to a mean maximal conductance $\left(G_{\max }\right)$ of $10.4 \pm$ $4.8 \mathrm{nS}$. Based on a whole-cell capacitance $\left(C_{\mathrm{M}}\right)$ of $35.1 \pm 17.5 \mathrm{pF}$ $(n=10)$, this corresponded to a current density $\left(I_{\mathrm{Ca} \text {,tail }}{ }_{\max } C_{\mathrm{M}}{ }^{-1}\right.$,

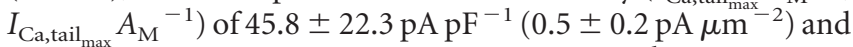
a conductance density of $354.2 \pm 171.8 \mathrm{pS} \mathrm{pF}^{-1}(3.5 \pm 1.7 \mathrm{pS}$ $\mu \mathrm{m}^{-2}$ ). Steady-state inactivation (supplemental Fig. 2, available at www.jneurosci.org as supplemental material) started at prepulse potentials around $-80 \mathrm{mV}$ and increased with the amplitude of the depolarizing prepulse. The voltage for half-maximal inactivation $\left(V_{0.5_{\text {inact }}}\right)$ was $-30 \pm 7.4 \mathrm{mV}\left(s_{\text {inact }}=18.3 \pm 1.5\right.$; $n=10)$.

\footnotetext{
$\leftarrow$

glomeruli. The density of neurites varied between glomeruli as shown in detail in the inset (70 $\mu$ m image stack). The outlined glomeruli are fully contained in the image stacks. E1, E2, Images of another type I LN demonstrating the variation in the density of neurites between different glomeruli. The position of the soma (S) that was lost during processing is marked (*). The inset shows a different $z$-stack demonstrating the innervation of the macroglomerulus (outlined region), which is fully contained in the image stack $(70 \mu \mathrm{m})$. E2, Higher magnification of the frame in $\boldsymbol{E} 1$ demonstrating that the neuron gave rise to the y-shaped tract (YST). The outlined glomeruli are fully contained in the image stack $(70 \mu \mathrm{m}) \boldsymbol{F}$, Double labeling (yellow) of a type I LN that was stained with biocytin/streptavidin (red) and exhibited GLIR (green). The position of

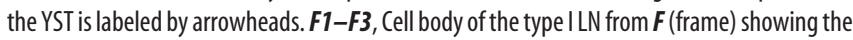
biocytin/streptavidin label (red) in $\boldsymbol{F}$, the GLIR (green) in $\boldsymbol{F}$, and both labels overlaid (yellow) in F3. YST, y-shaped tract; for the other abbreviations, see legend of Figure 2. Scale bars: $\boldsymbol{D}, 100$ $\mu \mathrm{m} ; \boldsymbol{D}$ inset, $20 \mu \mathrm{m} ; \boldsymbol{E 1}, 100 \mu \mathrm{m} ; \boldsymbol{E 1}$ inset, $\boldsymbol{E 2}, \boldsymbol{F}, \boldsymbol{F 1}, \boldsymbol{F 2}, \boldsymbol{F} \mathbf{3}, 50 \mu \mathrm{m}$.
} 


\section{type II local interneuron}

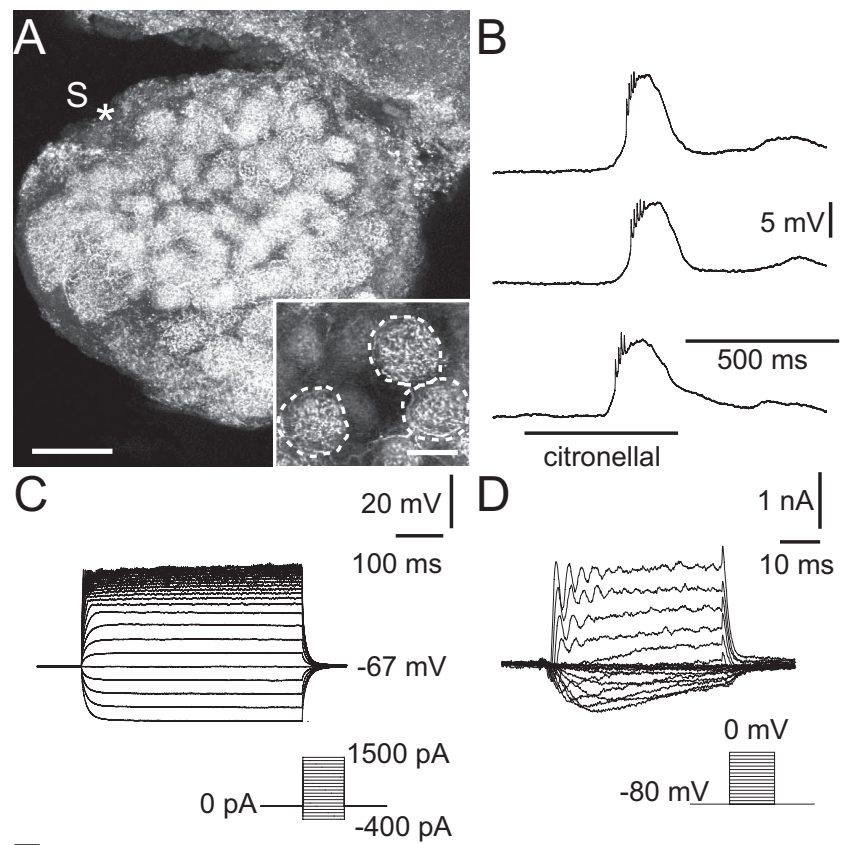

E

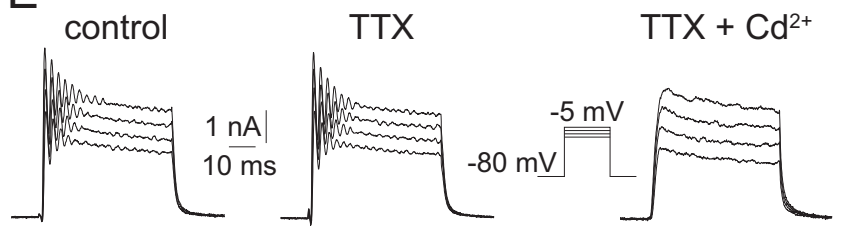

$0 \mathrm{~min}$

$15 \min$
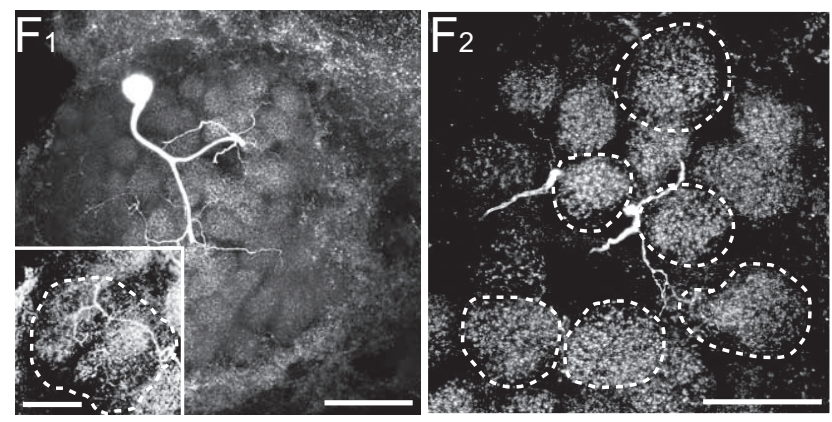

Figure 4. Type II LN: electrophysiological and morphological characteristics. A, Morphology of the recorded neuron. The position of the soma $(S)$ that was lost during processing is marked $\left({ }^{*}\right)$. The neuron innervated all glomeruli and the distribution of neurites was similar in all glomeruli. This is demonstrated with the inset, in which three glomeruli are outlined that are fully contained in the image stack $(70 \mu \mathrm{m}) . \boldsymbol{B}, \boldsymbol{C}$, Odor stimulation $(\boldsymbol{B})$ and injection of depolarizing current $(\boldsymbol{C})$ did not induce overshooting action potentials. $\boldsymbol{B}, 0$ dor stimulation induced a graded depolarization and not $\mathrm{Na}^{+}$-driven spikelets, but no overshooting $\mathrm{Na}^{+}$-driven action potentials. $C$, The neuron showed rectification during injection of large depolarizing currents, but never generated overshooting, $\mathrm{Na}^{+}$driven action potentials. Current was injected for $500 \mathrm{~ms}$ from -400 to $1500 \mathrm{pA}$ in $100 \mathrm{pA}$ steps. $\boldsymbol{D}$, Whole-cell recording of (mainly) voltage-activated currents in normal saline. Depolarizing voltage steps from a holding potential of $-80 \mathrm{mV}$ did not elicit transient, $\mathrm{TTX}$-sensitive $\mathrm{Na}^{+}$currents. Voltage steps to membrane potentials to between -55 and $-25 \mathrm{mV}$ revealed an inactivating $\mathrm{Ca}^{2+}$ current. More depolarizing voltage steps to membrane potentials between -20 and $0 \mathrm{mV}$ evoked outward $\mathrm{K}^{+}$currents with 4-AP- and TEA-sensitive components. $\boldsymbol{E}$, The oscillations that occurred at the beginning of these voltage steps were insensitive to high concentrations of $\operatorname{TX}\left(10^{-4} \mathrm{M}\right)$, but could be blocked by $\mathrm{Cd}^{2+}\left(5 \times 10^{-4} \mathrm{M}\right)$. $F \mathbf{F}$, Image of another type II LN demonstrating the homogeneous innervation of each glomerulus ( $90 \mu \mathrm{m}$ image stack). The inset shows a different $z$-stack demonstrating the innervation of the macroglomerulus ( $90 \mu$ m image stack). F2, Higher magnification substack from the neuron shown in $\boldsymbol{E} 1$ further demonstrates the homogenous glomerular innervation. The outlined glomeruli are fully contained in the image stack $(70 \mu \mathrm{m})$. For abbreviations, see the legend of Figure 2. Scale bars: $\boldsymbol{A}, 100 \mu \mathrm{m} ; \boldsymbol{A}$ inset, $20 \mu \mathrm{m} ; \boldsymbol{F 1}, 100 \mu \mathrm{m} ; \boldsymbol{F} \mathbf{1}$ inset, $\boldsymbol{F 2}, 50 \mu \mathrm{m}$.
$\mathrm{I}_{\mathrm{Ca}}$ in type II LNs

In type II LNs, $I_{\mathrm{Ca}}$ started to activate with voltage steps more depolarized than $-50 \mathrm{mV}$ (Fig. $5 A, B$ ). The peak current reached its maximum amplitude $\left(I_{\mathrm{Ca}_{\max }}\right)$ of $3.0 \pm 1.0 \mathrm{nA}$ at $-7.5 \pm 7.2 \mathrm{mV}$ $(n=12)$ (Fig. $5 B)$. The first-order Boltzmann fit of the tail currents had a voltage for half-maximal activation $\left(V_{0.5_{\text {act }}}\right)$ of $-19.4 \pm 4.7 \mathrm{mV}\left(s_{\text {act }}=6.4 \pm 2.3 ; n=12\right)$ (Fig. 5D). The tail currents had a maximum amplitude of $3.3 \pm 1.2 \mathrm{nA}(n=12)$ corresponding to a maximal conductance $\left(G_{\max }\right)$ of $21.9 \pm 7.7$ $\mathrm{nS}$. Based on a whole-cell capacitance of $96.5 \pm 30.2 \mathrm{pF}(n=12)$, this corresponded to a current density of $35.7 \pm 11.0 \mathrm{pA} \mathrm{pF}$ $\left(0.4 \pm 0.1 \mathrm{pA} \mu \mathrm{m}^{-2}\right)$ and a conductance density of $235.6 \pm 73.4$ $\mathrm{pS} \mathrm{pF}^{-1}\left(2.4 \pm 0.7 \mathrm{pS} \mu \mathrm{m}^{-2}\right)$. Steady-state inactivation (supplemental Fig. 2, available at www.jneurosci.org as supplemental material) started at prepulse potentials around $-65 \mathrm{mV}$ and had a voltage for half-maximal inactivation $\left(V_{0.5_{\text {inact }}}\right)$ of $-30 \pm 7.2$ $\mathrm{mV}\left(s_{\text {inact }}=13.8 \pm 0.5 ; n=12\right)$.

\section{Differences of $\mathrm{I}_{\mathrm{Ca}}$ between cell types}

In all investigated cell types, the current waveforms and physiological properties of $I_{\mathrm{Ca}}$ were typical for voltage-activated $\mathrm{Ca}^{2+}$ currents and in the range of other insect preparations [A. mellifera, antennal motorneurons (Kloppenburg et al., 1999a) and Kenyon cells (Schäfer et al., 1994); D. melanogaster, embryonic neurons (Byerly and Leung, 1988; Saito and Wu, 1991); Gryllus bimaculatus, giant interneurons (Kloppenburg and Hörner, 1998); P. americana, embryonic cockroach neurons (Benquet et al., 1999) and DUM neurons (Wicher and Penzlin, 1994); Manduca sexta, motor neurons (Hayashi and Levine, 1992); S. americana, thoracic neurons (Laurent et al., 1993); Schistocerca gregaria, DUM neurons (Heidel and Pflüger, 2006) and thoracic neurons (Pearson et al., 1993) ]. However, a quantitative comparison of the functional properties from $I_{\mathrm{Ca}}$ between the different cell types revealed significant differences in some physiologically important parameters (for summary, see supplemental Table 1, available at www.jneurosci.org as supplemental material).

Perhaps physiologically most relevant was the difference in voltage dependence of $I_{\mathrm{Ca}}$ in the three cell types that we quantified by analyzing the tail currents (Fig. $5 C, D$ ). In type II LNs, which do not generate $\mathrm{Na}^{+}$-driven action potentials, the voltage for halfmaximal activation (type II LNs, $V_{0.5}=-19.4 \pm 4.7 \mathrm{mV} ; n=$ 12) was significantly more hyperpolarized than in uPNs (uPN, $V_{0.5}=-10.6 \pm 3.4 \mathrm{mV} ; n=12 ; p<0.001$ ) and type I LNs (type I LNs, $V_{0.5_{\text {act }}}=-11.1 \pm 6.5 \mathrm{mV} ; n=10 ; p<0.001$ ), in both of which the voltage for half-maximal activation was very similar $(p=0.8)$. Furthermore, the membrane potential at which the peak current reached its maximum amplitude was significantly more hyperpolarized in type II LNs $(-7.5 \pm 7.2 \mathrm{mV} ; n=12)$ than in uPNs $(5.8 \pm 4.9 \mathrm{mV} ; n=12 ; p<0.001)$ and type I LNs $(9.0 \pm 6.1 \mathrm{mV} ; n=10 ; p<0.001)$. The difference between type I LNs and uPNs was not significant $(p=0.2)$.

Most obvious was the difference in current amplitude (Fig. $5 A, B)$. In type II LNs (type II LNs, $I_{\mathrm{Ca}_{\max }}=3.0 \pm 1.0 \mathrm{nA} ; n=12$ ), the mean maximal amplitude of $I_{\mathrm{Ca}}$ was significantly larger compared with uPNs (uPN, $I_{\max }=1.4 \pm 0.4 \mathrm{nA} ; n=12 ; p<0.001$ ) and type I LNs (type I LNs, $I_{\max }=1.0 \pm 0.3 \mathrm{nA} ; n=10 ; p<$ $0.001)$, whereas there is no significant difference in the maximal amplitude of $I_{\mathrm{Ca}}$ between uPNs and type I LNs $(p=0.2)$. The large amplitude of $I_{\mathrm{Ca}}$ in type II LNs, however, was put into perspective when we compared the current densities $\left(I_{\mathrm{Ca}_{\max }} A_{\mathrm{M}}{ }^{-1}\right)$ between the cell types. uPNs had a significantly higher current density (uPNs, $I_{\mathrm{Ca}_{\max }} A_{\mathrm{M}}{ }^{-1}=0.9 \pm 0.3 \mathrm{pA} \mu \mathrm{m}^{-2} ; n=12$ ) than both types of local interneurons (for both, $p<0.001$ ), in which 
A

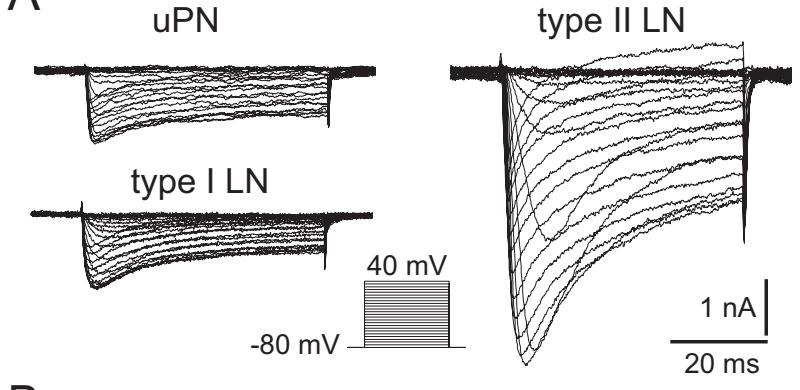

B

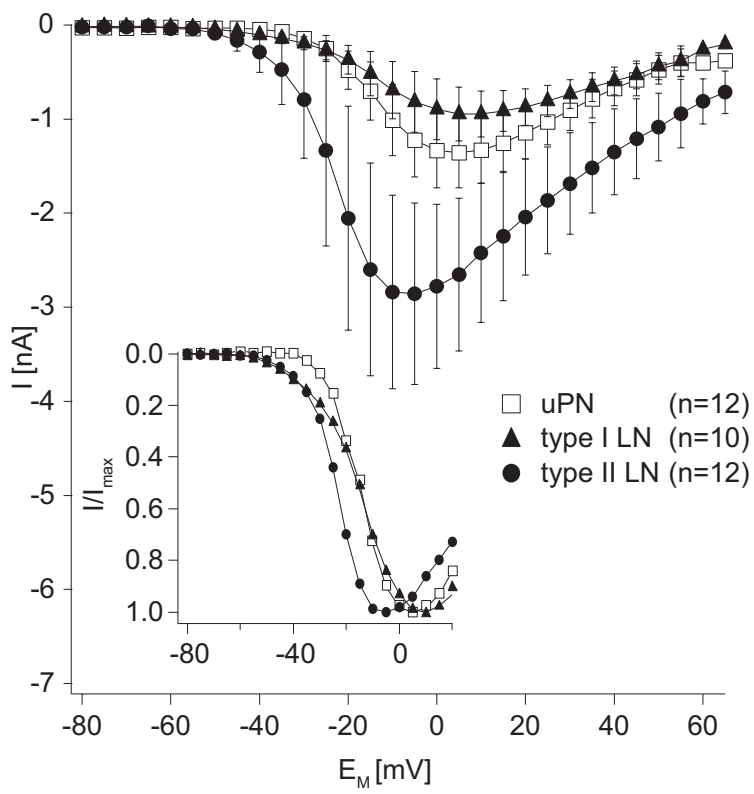

C

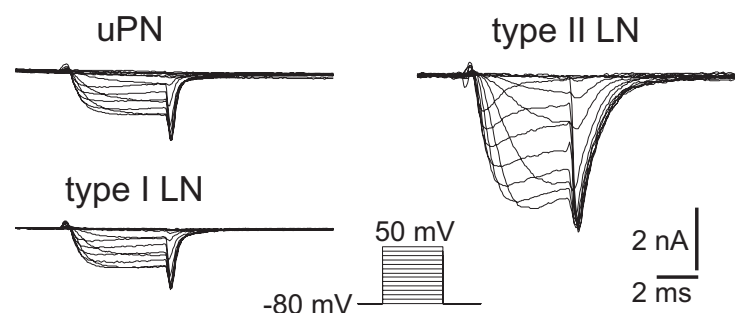

D

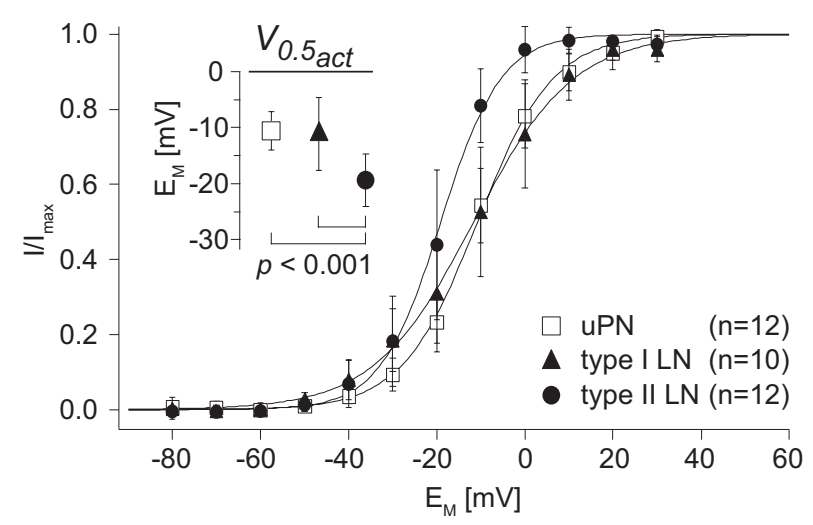

Figure 5. Characterization of the $\mathrm{Ca}^{2+}$ currents $\left(I_{\mathrm{C}}\right)$ from uPNs, type I LNs, and type II LNs. $A$, Example current traces for steady-state activation of $I_{\mathrm{Ca}_{\mathrm{a}}}$ from a uPN, a type I LN, and a type II $\mathrm{LN}$. The holding potential was $-80 \mathrm{mV}$ and neurons were depolarized for $50 \mathrm{~ms}$ to at least 40 $\mathrm{mV}$ in $5 \mathrm{mV}$ increments. Note that the current amplitude is much larger in the type II LN than in the uPN and type I LN. $\boldsymbol{B}, I-V$ relationships of $I_{C}$ recorded from uPNs, type I LNs, and type II LNs. The inset shows the normalized $I-V$ relationships to better demonstrate differences in the the current densities were similar (type I LN, $I_{\mathrm{Ca}} \quad A_{\mathrm{M}}{ }^{-1}=0.5 \pm$ $0.2 \mathrm{pA} \mu \mathrm{m}^{-2} ; n=10$; type II LN, $I_{\mathrm{Ca}_{\max }} A_{\mathrm{M}} \stackrel{-\mathrm{I}_{\max }}{=} 0.4 \pm 0.1 \mathrm{pA}$ $\left.\mu \mathrm{m}^{-2} ; n=12 ; p=0.8\right)$.

\section{Discussion}

Our results show that the olfactory network of $P$. americana contains LNs with marked differences in intrinsic firing properties and $\mathrm{Ca}^{2+}$ currents that may lead to differences in synaptic transmission and thus the role these neurons play in olfactory information processing networks. We found that type II LNs did not express transient voltage-activated $\mathrm{Na}^{+}$currents and that the voltage dependence of $I_{\mathrm{Ca}}$ was shifted to more hyperpolarized membrane potentials than in type I LNs. The two LN types were also morphologically distinguishable: type I LNs innervated many, but not all glomeruli. They had varying innervation densities between glomeruli and exhibited GLIR. This type of LN has been described previously as y-neurons (Ernst and Boeckh, 1983). In type II LNs, apparently all glomeruli are innervated without obvious differences in innervation pattern between glomeruli, and $90 \%$ of them did not show GLIR.

\section{Types of local interneurons}

The important role of local interneurons for olfactory information processing has been demonstrated in various studies (Stopfer et al., 1997; Sachse and Galizia, 2002; Wilson et al., 2004; Wilson and Laurent, 2005). The possibility, however, of different morphological and physiological properties of LN subpopulations have not been considered in detail. In many insect species, odor stimulation induces depolarization and the generation of action potentials (Matsumoto and Hildebrand, 1981; Christensen et al., 1993; Sun et al., 1993; Hansson et al., 1994; Han et al., 2005; Wilson and Laurent, 2005), and although the underlying ionic currents were generally not specifically determined, it was assumed that their action potentials were driven by $\mathrm{Na}^{+}$. Only for locusts is there evidence that LNs do not generate $\mathrm{Na}^{+}$driven action potentials (Laurent and Davidowitz, 1994), but instead, graded TTX-resistant active potentials, which might be driven by $\mathrm{Ca}^{2+}$ as suggested by Laurent (1996). The distinctive physiological characteristics of the LN types that we describe imply important consequences for their computational properties and the olfactory processing that they perform. First, the LNs differ in intrinsic firing characteristics that determine their signal conducting and integrative properties. Second, they vary in their $\mathrm{Ca}^{2+}$ currents, possibly leading to different kinetics and timescale of synaptic transmitter release. Our results suggest that olfactory information can be processed in the same network in parallel from LNs that use spikes and others that use analog signals for intercellular communication.

\footnotetext{
$\leftarrow$

voltage dependence (for a quantitative comparison, see $\boldsymbol{D}$, inset). In uPNs, the peak current reached its maximum amplitude $\left(I_{\max }\right)$ of $1.4 \pm 0.4 \mathrm{nA}$ at $5.8 \pm 4.9 \mathrm{mV}(n=12)$. In type I LNs, the $I_{\text {max }}$ of $1.0 \pm 0.3 \mathrm{nA}$ was reached at $9.0 \pm 6.1 \mathrm{mV}(n=10)$, and in type II LNs, the $I_{\text {max }}$ of $3.0 \pm 1.0 \mathrm{nA}$ was reached at $-7.5 \pm 7.2 \mathrm{mV}(n=12)$. C, Example current traces for steadystate activation of tail currents ( $\left.I_{\text {Ca,tail }}\right)$ from a uPN, a type I LN, and a type II LN. The holding potential was $-80 \mathrm{mV}$, and neurons were depolarized for $5 \mathrm{~ms}$ to $50 \mathrm{mV}$ in $10 \mathrm{mV}$ increments. D, I-V relationships of normalized tail currents. Before averaging, the tail currents were normalized to the maximum tail current of each cell. Curves are fits to a first-order Boltzmann relationship (Eq. 1) with the following parameters: $\mathrm{UPN}, V_{0.5 \text { act }}=-10.6 \pm 3.4 \mathrm{mV}, S_{\text {act }}=$ $8.5 \pm 1.8, n=12$; type I LN, $V_{0.5}=-11.1 \pm 6.5 \mathrm{mV}, s_{\text {act }}=10.0 \pm 2.3, n=10$; type II LN, $V_{0.5 \text { act }}=-19.4 \pm 4.7 \mathrm{mV}, S_{\text {act }}=6.4 \pm 2.3, n=12 . D$, Inset, In type II LNs, the voltage for half-maximal activation $\left(V_{0.5 \mathrm{acc}}\right)$ was significantly $(p<0.001)$ more hyperpolarized than in uPNs and in type I LNs, in which the $V_{0.5 \text { act }}$ was very similar $(p=0.8)$.
} 
To our knowledge, this is the first time that LNs that generate $\mathrm{Na}^{+}$-driven APs and LNs that do not are explicitly described in the AL of the same insect species and that these findings are substantiated by voltage-clamp recordings. In a broader context, however, our findings should not be a total surprise, because we know from other insect sensory systems (e.g., the mechanosensory system in the thoracic ganglia) (for review, see Burrows, 1996) that sensory information can be processed in parallel in spiking and nonspiking neurons.

Although the precise synaptic organization can only be revealed by electron microscopic studies, some hypotheses about the synaptic input and output regions of the LNs can be formed from our confocal images. Type I LNs expressed differential branching patterns in different glomeruli suggesting a polar organization with defined input and output regions (Distler and Boeckh, 1997b). According to this hypothesis, the synaptic input from a defined receptive field (e.g., one or a few glomeruli) would be integrated into action potential firing that would spread to other innervated glomeruli, and provide a defined array of glomeruli with synaptic input. In contrast, type II LNs have very similar branching patterns in all glomeruli, suggesting that they can receive synaptic input from all innervated glomeruli. However, during odor stimulation, synaptic input from olfactory receptor neurons will be typically restricted to certain glomeruli, in which graded postsynaptic potentials will be generated. In nonspiking neurons, these potentials will spread only within the same glomerulus or to glomeruli that are electrotonically close to the stimulated glomerulus.

Historically, LNs have been regarded mostly as GABAergic, inhibitory neurons, and GABAergic LNs have been reported in the AL of various insect species including A. mellifera (Schäfer and Bicker, 1986), Bombyx mori (Iwano and Kanzaki, 2005; Seki and Kanzaki, 2008), D. melanogaster (Wilson and Laurent, 2005), M. sexta (Hoskins et al., 1986), P. americana (Distler, 1989), and S. americana (Leitch and Laurent, 1996). Immunohistochemical, mass-spectrometric and physiological studies, however, showed that the LNs are biochemically a more heterogeneous population of neurons than previously thought. In addition to GABAergic and inhibitory neurons, there are also LNs that contain and probably release various peptides, biogenic amines (for review, see Homberg and Müller, 1999; Schachtner et al., 2005; Nässel and Homberg, 2006) and acetylcholine (Shang et al., 2007). To that effect, they have been shown to provide excitatory synaptic input to follower cells (Olsen et al., 2007; Shang et al., 2007). Our finding that type I LNs show GLIR is in agreement with the studies by Distler (1989), who showed that LNs projecting through the characteristic y-shaped tract exhibit GLIR. Ninety percent of the type II LNs that have a different morphology and do not generate $\mathrm{Na}^{+}$-driven APs, do not exhibit GLIR. Future studies should reveal what transmitter type II LNs release and whether they act inhibitory or excitatory.

\section{Voltage-activated $\mathrm{Ca}^{2+}$ currents}

Consistent with the distinct electrophysiological characteristics, we revealed differences in the functional parameters of $I_{\mathrm{Ca}}$ between the different LN types. Given the complex morphology of the investigated neurons, perfect voltage control across the whole neuron cannot be assumed. In our recordings, however, blocking all voltage-activated non- $\mathrm{Ca}^{2+}$ currents made the neurons electrotonically more compact. Under these conditions, the waveforms of $I_{\mathrm{Ca}}$ did not indicate voltage control problems (e.g., no delay of current onset, no jumps in the voltage dependence). We conclude that the recorded $I_{\mathrm{Ca}}$ originated mostly from well voltage-clamped regions of the neurons, suggesting that the differences in voltage dependence of $I_{\mathrm{Ca}}$ indeed reflect functional differences of $I_{\mathrm{Ca}}$ between cell types. This line of arguments is supported by in vitro recordings from acutely dissociated, perfectly spherical cell bodies of (unidentified) AL neurons. We found versions of $I_{\mathrm{Ca}}$ that are virtually identical to the currents found in type I LNs on the one hand and type II LNs on the other (supplemental Fig. 3, available at www.jneurosci.org as supplemental material) (Husch et al., 2008).

In both $\mathrm{LN}$ types, $I_{\mathrm{Ca}}$ starts to activate at membrane potentials around $-50 \mathrm{mV}$ (Fig. $5 B$ ). This is a relatively low activation threshold compared with $I_{\mathrm{Ca}}$ in uPNs and in many other insect neurons (Byerly and Leung, 1988; Saito and Wu, 1991; Hayashi and Levine, 1992; Laurent et al., 1993; Pearson et al., 1993; Schäfer et al., 1994; Wicher and Penzlin, 1994, 1997; Kloppenburg and Hörner, 1998; Benquet et al., 1999; Kloppenburg et al., 1999a; Heidel and Pflüger, 2006). In type II LNs, despite the similar activation threshold in both LN types, the half-maximal voltage for activation is significantly more hyperpolarized than in type I LNs (Fig. $5 B, D$ ). Accordingly, the portion of $I_{\mathrm{Ca}}$ that can be activated at hyperpolarized membrane potentials is larger in type II LNs. This is consistent with the assumption that the synaptic release in these neurons is regulated by analog changes in the membrane potential, as suggested for olfactory LNs in the AL of the locust (MacLeod and Laurent, 1996).

In insects, nonspiking local interneurons have been studied in great detail in the mechanosensory system in the thoracic ganglion of the locust (for review, see Burrows, 1996) including voltage-clamp studies of voltage-activated $\mathrm{Ca}^{2+}$ currents (Laurent et al., 1993). The $\mathrm{Ca}^{2+}$ currents underlying graded transmission in invertebrates have been most extensively studied in leech heart interneurons (Angstadt and Calabrese, 1991; Lu et al., 1997; Ivanov and Calabrese, 2000, 2006). Similar to the type II LNs, they have relatively hyperpolarized activation ranges with an activation threshold of $-55 \mathrm{mV}$ (Angstadt and Calabrese, 1991). In vertebrates, $\mathrm{Ca}^{2+}$ currents are functionally classified into lowvoltage-activated (LVA or T-type) (with activation starting above approximately $-70 \mathrm{mV}$ ) and high-voltage-activated (HVA) (activation starting above approximately $-30 \mathrm{mV}$ ) classes. HVA subtypes such as L-, P/Q-, N-, and R-type are defined by their biophysical and pharmacological properties (Ertel et al., 2000; Hille, 2001; Triggle, 2006). In accordance with previous studies (for review, see King, 2007), we found that the pharmacological classification of vertebrate $\mathrm{Ca}^{2+}$ currents is difficult to match with the $I_{\mathrm{Ca}}$ in AL neurons of $P$. americana (Husch et al., 2008).

We revealed that the olfactory LNs from the AL consist, at least in P. americana, of physiologically distinct classes of neurons. The results suggest important differences in the properties of LNs to compute olfactory information. Our findings imply that olfactory information is processed in parallel by LNs that use APs and LNs that use analog signals for intercellular communication.

\section{References}

Abel R, Rybak J, Menzel R (2001) Structure and response patterns of olfactory interneurons in the honeybee, Apis mellifera. J Comp Neurol 437:363-383.

Angstadt JD, Calabrese RL (1991) Calcium currents and graded synaptic transmission between heart interneurons of the leech. J Neurosci 11:746-759.

Armstrong CM, Bezanilla F (1974) Charge movement associated with the opening and closing of the activation gates of the Na channels. J Gen Physiol 63:533-552.

Bazhenov M, Stopfer M, Sejnowski TJ, Laurent G (2005) Fast odor learning 
improves reliability of odor responses in the locust antennal lobe. Neuron 46:483-492.

Benkenstein C, Schmidt M, Gewecke M (1999) Voltage-activated wholecell $\mathrm{K}^{+}$currents in lamina cells of the desert locust Schistocerca gregaria. J Exp Biol 202:1939-1951.

Benquet P, Guen JL, Dayanithi G, Pichon Y, Tiaho F (1999) omegaAgaIVA-sensitive (P/Q-type) and -resistant (R-type) high-voltageactivated $\mathrm{Ba}^{2+}$ currents in embryonic cockroach brain neurons. J Neurophysiol 82:2284-2293.

Boeckh J, Ernst KD (1987) Contribution of single unit analysis in insects to an understanding of olfactory function. J Comp Physiol A Neuroethol Sens Neural Behav Physiol 161:549-565.

Broome BM, Jayaraman V, Laurent G (2006) Encoding and decoding of overlapping odor sequences. Neuron 51:467-482.

Burrows M (1996) The neurobiology of an insect brain. New York: Oxford UP.

Burrows M, Boeckh J, Esslen J (1982) Physiological and morphological properties of interneurones in the deutocerebrum of male cockroaches which respond to female pheromone. J Comp Physiol A Neuroethol Sens Neural Behav Physiol 145:447-457.

Byerly L, Leung HT (1988) Ionic currents of Drosophila neurons in embryonic cultures. J Neurosci 8:4379-4393.

Christensen TA, Waldrop BR, Harrow ID, Hildebrand JG (1993) Local interneurons and information processing in the olfactory glomeruli of the moth Manduca sexta. J Comp Physiol A Neuroethol Sens Neural Behav Physiol 173:385-399.

Davis RL (2004) Olfactory learning. Neuron 44:31-48.

Distler P (1989) Histochemical demonstration of GABA-like immunoreactivity in cobalt labeled neuron individuals in the insect olfactory pathway. Histochemistry 91:245-249.

Distler PG, Boeckh J (1997a) Synaptic connections between identified neuron types in the antennal lobe glomeruli of the cockroach, Periplaneta americana: I. Uniglomerular projection neurons. J Comp Neurol 378:307-319.

Distler PG, Boeckh J (1997b) Synaptic connections between identified neuron types in the antennal lobe glomeruli of the cockroach, Periplaneta americana: II. Local multiglomerular interneurons. J Comp Neurol 383:529-540.

Distler PG, Gruber C, Boeckh J (1998) Synaptic connections between GABA-immunoreactive neurons and uniglomerular projection neurons within the antennal lobe of the cockroach, Periplaneta americana. Synapse 29:1-13.

Ernst KD, Boeckh J (1983) A neuroanatomical study on the organization of the central antennal pathways in insects. III. Neuroanatomical characterization of physiologically defined response types of deutocerebral neurons in Periplaneta americana. Cell Tissue Res 229:1-22.

Ertel EA, Campbell KP, Harpold MM, Hofmann F, Mori Y, Perez-Reyes E, Schwartz A, Snutch TP, Tanabe T, Birnbaumer L, Tsien RW, Catterall WA (2000) Nomenclature of voltage-gated calcium channels. Neuron 25:533-535.

Hamill OP, Marty A, Neher E, Sakmann B, Sigworth FJ (1981) Improved patch-clamp techniques for high-resolution current recording from cells and cell-free membrane patches. Pflugers Arch 391:85-100.

Han Q, Hansson BS, Anton S (2005) Interactions of mechanical stimuli and sex pheromone information in antennal lobe neurons of a male moth, Spodoptera littoralis. J Comp Physiol A Neuroethol Sens Neural Behav Physiol 191:521-528.

Hansson BS, Anton S, Christensen TA (1994) Structure and function of antennal lobe neurons in the male turnip moth, Agrotis segetum (lepidoptera, noctuidae). J Comp Physiol A Neuroethol Sens Neural Behav Physiol 175:547-562.

Hayashi JH, Levine RB (1992) Calcium and potassium currents in leg motoneurons during postembryonic development in the hawkmoth Manduca sexta. J Exp Biol 171:15-42.

Heidel E, Pflüger HJ (2006) Ion currents and spiking properties of identified subtypes of locust octopaminergic dorsal unpaired median neurons. Eur J Neurosci 23:1189-1206.

Hildebrand JG, Shepherd GM (1997) Mechanisms of olfactory discrimination: converging evidence for common principles across phyla. Annu Rev Neurosci 20:595-631.

Hille B (2001) Ion channels of excitable membranes. Sunderland, MA: Sinauer Associates.
Homberg U, Müller U (1999) Neuroactive substances in the antennal lobe. In: Insect olfaction (Hansson BS, ed), pp 181-206. Berlin, Heidelberg, New York: Springer.

Hoskins SG, Homberg U, Kingan TG, Christensen TA, Hildebrand JG (1986) Immunocytochemistry of GABA in the antennal lobes of the sphinx moth Manduca sexta. Cell Tissue Res 244:243-252.

Husch A, Hess S, Kloppenburg P (2008) Functional parameters of voltageactivated $\mathrm{Ca}^{2+}$ currents from olfactory interneurons in the antennal lobe of Periplaneta americana. J Neurophysiol 99:320-332.

Ivanov AI, Calabrese RL (2000) Intracellular $\mathrm{Ca}^{2+}$ dynamics during spontaneous and evoked activity of leech heart interneurons: low-threshold Ca currents and graded synaptic transmission. J Neurosci 20:4930-4943.

Ivanov AI, Calabrese RL (2006) Graded inhibitory synaptic transmission between leech interneurons: assessing the roles of two kinetically distinct low-threshold Ca currents. J Neurophysiol 96:218-234.

Iwano M, Kanzaki R (2005) Immunocytochemical identification of neuroactive substances in the antennal lobe of the male silkworm moth Bombyx mori. Zoolog Sci 22:199-211.

Kanzaki R, Arbas EA, Strausfeld NJ, Hildebrand JG (1989) Physiology and morphology of projection neurons in the antennal lobe of the male moth Manduca sexta. J Comp Physiol A Neuroethol Sens Neural Behav Physiol 165:427-453.

King GF (2007) Modulation of insect $\mathrm{Ca}_{(\mathrm{v})}$ channels by peptidic spider toxins. Toxicon 49:513-530.

Kloppenburg P, Hörner M (1998) Voltage-activated currents in identified giant interneurons isolated from adult crickets Gryllus bimaculatus. J Exp Biol 201:2529-2541.

Kloppenburg P, Kirchhof BS, Mercer AR (1999a) Voltage-activated currents from adult honeybee (Apis mellifera) antennal motor neurons recorded in vitro and in situ. J Neurophysiol 81:39-48.

Kloppenburg P, Ferns D, Mercer AR (1999b) Serotonin enhances central olfactory neuron responses to female sex pheromone in the male sphinx moth Manduca sexta. J Neurosci 19:8172-8181.

Kloppenburg P, Zipfel WR, Webb WW, Harris-Warrick RM (2000) Highly localized $\mathrm{Ca}^{2+}$ accumulation revealed by multiphoton microscopy in an identified motoneuron and its modulation by dopamine. J Neurosci 20:2523-2533.

Laurent G (1996) Dynamical representation of odors by oscillating and evolving neural assemblies. Trends Neurosci 19:489-496.

Laurent G, Davidowitz H (1994) Encoding of olfactory information with oscillating neural assemblies. Science 265:1872-1875.

Laurent G, Seymour-Laurent KJ, Johnson K (1993) Dendritic excitability and a voltage-gated calcium current in locust nonspiking local interneurons. J Neurophysiol 69:1484-1498.

Leitch B, Laurent G (1996) GABAergic synapses in the antennal lobe and mushroom body of the locust olfactory system. J Comput Neurosci 372:487-514.

Lu J, Dalton JF 4th, Stokes DR, Calabrese RL (1997) Functional role of $\mathrm{Ca}^{2+}$ currents in graded and spike-mediated synaptic transmission between leech heart interneurons. J Neurophysiol 77:1779-1794.

MacLeod K, Laurent G (1996) Distinct mechanisms for synchronization and temporal patterning of odor-encoding neural assemblies. Science 274:976-979.

Malun D, Waldow U, Kraus D, Boeckh J (1993) Connections between the deutocerebrum and the protocerebrum, and neuroanatomy of several classes of deutocerebral projection neurons in the brain of male Periplaneta americana. J Comp Neurol 329:143-162.

Masante-Roca I, Gadenne C, Anton S (2005) Three-dimensional antennal lobe atlas of male and female moths, Lobesia botrana (Lepidoptera: Tortricidae) and glomerular representation of plant volatiles in females. J Exp Biol 208:1147-1159.

Matsumoto SG, Hildebrand JG (1981) Olfactory mechanisms in the moth Manduca sexta: response characteristics and morphology of central neurons in the antennal lobes. Proc R Soc Lond B Biol Sci 213:249-277.

Namiki S, Iwabuchi S, Kanzaki R (2008) Representation of a mixture of pheromone and host plant odor by antennal lobe projection neurons of the silkmoth Bombyx mori. J Comp Physiol A Neuroethol Sens Neural Behav Physiol 194:501-515.

Nässel DR, Homberg U (2006) Neuropeptides in interneurons of the insect brain. Cell Tissue Res 326:1-24.

Olsen SR, Wilson RI (2008) Lateral presynaptic inhibition mediates gain control in an olfactory circuit. Nature 452:956-960. 
Olsen SR, Bhandawat V, Wilson RI (2007) Excitatory interactions between olfactory processing channels in the Drosophila antennal lobe. Neuron 54:89-103.

Pearson HA, Lees G, Wray D (1993) Calcium-channel currents in neurons from locust (Schistocerca gregaria) thoracic ganglia. J Exp Biol 177:201-221.

Sachse S, Galizia CG (2002) Role of inhibition for temporal and spatial odor representation in olfactory output neurons: a calcium imaging study. J Neurophysiol 87:1106-1117.

Saito M, Wu CF (1991) Expression of ion channels and mutational effects in giant Drosophila neurons differentiated from cell division-arrested embryonic neuroblasts. J Neurosci 11:2135-2150.

Schachtner J, Schmidt M, Homberg U (2005) Organization and evolutionary trends of primary olfactory brain centers in Tetraconata (Crustacea plus Hexapoda). Arthropod Struct Dev 34:257-299.

Schäfer S, Bicker G (1986) Distribution of GABA-like immunoreactivity in the brain of the honeybee. J Comp Neurol 246:287-300.

Schäfer S, Rosenboom H, Menzel R (1994) Ionic currents of Kenyon cells from the mushroom body of the honeybee. J Neurosci 14:4600-4612.

Seki Y, Kanzaki R (2008) Comprehensive morphological identification and GABA immunocytochemistry of antennal lobe local interneurons in Bombyx mori. J Comp Neurol 506:93-107.

Shang Y, Claridge-Chang A, Sjulson L, Pypaert M, Miesenböck G (2007) Excitatory local circuits and their implications for olfactory processing in the fly antennal lobe. Cell 128:601-612.

Stopfer M, Laurent G (1999) Short-term memory in olfactory network dynamics. Nature 402:664-668.

Stopfer M, Bhagavan S, Smith BH, Laurent G (1997) Impaired odour discrimination on desynchronization of odour-encoding neural assemblies. Nature 390:70-74.

Stopfer M, Jayaraman V, Laurent G (2003) Intensity versus identity coding in an olfactory system. Neuron 39:991-1004.
Strausfeld NJ, Hildebrand JG (1999) Olfactory systems: common design, uncommon origins? Curr Opin Neurobiol 9:634-639.

Sun XJ, Fonta C, Masson C (1993) Odor quality processing by bee antennal lobe interneurons. Chem Senses 18:355-377.

Sun XJ, Tolbert LP, Hildebrand JG (1997) Synaptic organization of the uniglomerular projection neurons of the antennal lobe of the moth Manduca sexta: a laser scanning confocal and electron microscopic study. J Comp Neurol 379:2-20.

Triggle DJ (2006) L-type calcium channels. Curr Pharm Des 12:443-457.

Vosshall LB, Stocker RF (2007) Molecular architecture of smell and taste in Drosophila. Annu Rev Neurosci 30:505-533.

Waldrop B, Christensen TA, Hildebrand JG (1987) GABA-mediated synaptic inhibition of projection neurons in the antennal lobes of the sphinx moth, Manduca sexta. J Comp Physiol A Neuroethol Sens Neural Behav Physiol 161:23-32.

Wehr M, Laurent G (1996) Odour encoding by temporal sequences of firing in oscillating neural assemblies. Nature 384:162-166.

Wicher D, Penzlin H (1994) $\mathrm{Ca}^{2+}$ currents in cockroach neurones: properties and modulation by neurohormone D. Neuroreport 5:1023-1026.

Wicher D, Penzlin H (1997) $\mathrm{Ca}^{2+}$ currents in central insect neurons: Electrophysiological and pharmacological properties. J Neurophysiol 77:186-199.

Wilson RI, Laurent G (2005) Role of GABAergic inhibition in shaping odorevoked spatiotemporal patterns in the Drosophila antennal lobe. J Neurosci 25:9069-9079.

Wilson RI, Mainen ZF (2006) Early events in olfactory processing. Annu Rev Neurosci 29:163-201.

Wilson RI, Turner GC, Laurent G (2004) Transformation of olfactory representations in the Drosophila antennal lobe. Science 303:366-370.

Yuste R, Gutnick MJ, Saar D, Delaney KR, Tank DW (1994) Ca ${ }^{2+}$ accumulations in dendrites of neocortical pyramidal neurons-an apical band and evidence for 2 functional compartments. Neuron 13:23-43. 